Historia Slavorum Occidentis

2021, nr 2 (29)

ISSN 2084-1213

DOI: $10.15804 /$ hso210207

\author{
MareK Šmíd (Praga)
}

ORCID: 0000-0001-8613-8673

\title{
František Kordač, arcybiskup praski i prymas Czech w latach 1919-1931. Wysoki dostojnik Kościoła, który nie został kardynałem
}

Keywords: František Kordač, Catholic Church, Czechoslovakia, Vatican

\begin{abstract}
The study deals with František Kordač, a Czech Church dignitary and university professor who became the Archbishop of Prague and the Czech Primate in 1919. The text is based on materials from Czech and foreign archives, e.g. the Vatican funds.
\end{abstract}

Niniejszy artykuł poświęcony jest osobie czeskiego księdza, wysokiego dostojnika Kościoła i profesora uniwersyteckiego, Františka Kordača, który latem 1919 r. został arcybiskupem praskim i czeskim prymasem. Mimo że należał do konserwatywnej elity katolickiej, której trudno było pogodzić się z nową sytuacją polityczną po 1918 r., stosunkowo szybko odnalazł się w warunkach nowej Czechosłowacji i zasiadł w jej Rewolucyjnym Zgromadzeniu Narodowym. Ze względu na swą rzymską formację, nieudawaną lojalność, szerokie horyzonty intelektualne oraz głębokie zrozumienie dla spraw narodowych stał się dla Stolicy Apostolskiej w nowych warunkach republikańskich idealnym pretendentem na tron biskupi św. Wojciecha w Pradze. W latach dwudziestych XX w. miał znaczący wkład do dziejów religii w młodej republice i przyczynił się do ustabilizowania religii katolickiej w zsekularyzowanej Czechosłowacji. Pomimo wysokiej rangi kapłaństwa, osobowości i wyjątkowych cech osobowych nigdy jednak nie został kardynałem. Celem tego studium jest znalezienie odpowiedzi, dlaczego do tego nie doszło. Studium bazuje na czeskich 
i zagranicznych archiwach, zwłaszcza archiwach watykańskich, a także na szerokiej literaturze przedmiotu.

František Kordač urodził się 11 I 1852 r. w wiosce Seletice niedaleko Rožd'alovic w północno-wschodnich Czechach ${ }^{1}$. Po ukończeniu ośmioletniego niemieckiego gimnazjum diecezjalnego dla chłopców w Bohosudovie (Mariaschein) rozpoczął studia teologiczne na Papieskim Uniwersytecie Gregoriańskim w Rzymie, gdzie w lipcu 1876 r. w Bazylice Świętego Jana na Lateranie (San Giovanni in Laterano) przyjął święcenia kapłańskie ${ }^{2}$. Jest niezaprzeczalnym faktem, że pobyt w Rzymie miał dla dalszych losów życia Kordača kluczowe znaczenie ze względu na to, iż z jezuickiego uniwersytetu w Wiecznym Mieście wyniósł zasady nowej polityki papieskiej (nacisk na edukację, posłuszeństwo Kościołowi itd.), które następnie aktywnie wprowadzał w Kościele narodowym. Rzymskie wykształcenie odcisnęło się jednakże nie tylko na osobowości F. Kordača, ale miało także niebagatelny wpływ na niego jako na myśliciela, naukowca, księdza, kaznodzieję i publicystę, dlatego można powiedzieć, że we Włoszech zostały określone i uformowane podstawowe cechy całokształtu osobowości Kordača. Jako dogłębnie wykształcony teolog i filozof po powrocie do Czech przewyższał intelektualnie kapłanów krajowych ${ }^{3}$.

W 1879 r. dwudziestosiedmioletni ksiądz F. Kordač powrócił do swojej ojczyzny. Następnie w pierwszej połowie lat osiemdziesiątych XIX w. pełnił posługę duszpasterską w Libercu w północnych Czechach, który był uznany za swoistą „stolicę” czeskich Niemców; wykorzystywał tam swoją dwujęzyczność i doświadczenie z kolegium niemieckiego w Rzymie. Pomimo to Liberec nie był dla rzymskokatolickiego księdza idealnym miejscem pracy. Był ważnym ośrodkiem, z którego rozprzestrzeniał się liberalizm i socjalizm na całe północne Czechy. We wczesnych latach osiemdziesiątych XIX w. osiągnęła swój szczyt także propaganda antyreligijna. Od 1871 r. w mieście działała Komisja wolnomyślicieli, a w 1882 r. powstała filia Wolnego Kościoła Rozumu ${ }^{4}$. Pomimo początkowego ciepłego przyjęcia wszedł później w konflikt z niektórymi lokalnymi radykalnymi Niemcami, którzy sprzeciwiali się jego zaangażowaniu na rzecz mniejszości czeskiej na północy.

1 Lidové listy, 10 I 1932.

2 Čech, 9 I 1927; Národní politika, 11 I 1927.

3 P. Marek, František Kordač, Archbishop of Prague: A Man Between Ultramontanism and Roman-Catholic Reformism, Cosmas. Czechoslovak and Central European Journal 19 (2005), c. 1, s. 9-26.

4 K.A. Huber, Franz Kordačs Briefe, Archiv für Kirchengeschichte von Böhmen-MährenSchlesien 1 (1967), s. 114. 
Sześć lat później F. Kordač został przeniesiony do Litoměřic, do siedziby biskupstwa o tej samej nazwie, gdzie został profesorem Nowego Testamentu i filozofii scholastycznej w miejscowym kapłańskim seminarium diecezjalnym, co pociągnęło za sobą włączenie go do pewnych sfer administracji kościelnej i dało mu możliwość uczestnictwa w zarządzaniu miejscowym Kościołem. W 1887 r. F. Kordačowi powierzono funkcję wicedyrektora seminarium, a dwa lata później został nawet mianowany rektorem - tenże akt pozwolił mu konsekwentnie realizować kompleksową przebudowę szkoły kapłańskiej. W ten sposób F. Kordač znacząco wpłynął na edukację i przeprowadził reformę studiów, wzmacniając dyscypliny filozoficzne 5

Ćwierć wieku pracy na niemieckiej północy Czech było dogłębnym sprawdzianem umiejętności F. Kordača jako kapłana i jako człowieka. Wykazał się dobrymi umiejętnościami organizacyjnymi, okazał się świetnym nauczycielem i wychowawcą. Zaprezentował się także w dziedzinie wystąpień publicznych i pracy w społeczności, co w owym czasie stanowiło integralną część życia ludzi. Mimo że nie odżegnywał się od swoich czeskich korzeni i walczył o równy status tych dwóch dominujących grup etnicznych w Czechach, starał się znaleźć ich modus vivendi oparte na sprawiedliwości i pojednaniu. Jego wieloletnie doświadczenie życiowe w kwestii współżycia Czechów i Niemców spowodowało, że należał do nielicznej grupki ludzi, którzy potrafili wyważyć swój nacjonalizm. Inną kwestią jest postrzeganie tego człowieka przez środowisko ukierunkowane nacjonalistycznie, a także wewnętrzna miara zadowolenia ambicji księdza, który na początku nowego wieku wkroczył w szóstą dekadę życia 6 .

Kiedy w 1904 r. na Wydziale Teologicznym Uniwersytetu Karola-Ferdynanda w Pradze, po odejściu na emeryturę profesora Eugena Kadeřávka, zostało zwolnione miejsce profesora uniwersyteckiego, F. Kordač znalazł się wśród kandydatów biorących udział w konkursie. Z drugiej strony, nie można nie zauważyć, że podjęcie pracy na praskim wydziale w 1905 r. było próbą wyjścia z walk i traum, które towarzyszyły mu przez dłuższy czas w północnych Czechach, gdzie najwyraźniej czuł się niedoceniany. Przyjazd Kordača do Pragi w sposób symboliczny dał początek drugiej połowie jego życia, którą przeżył co prawda w środowisku czeskim, ale która miała charakter podobny do wcześniejszego życia: cechowała ją działalność dydaktyczna

5 E. Čáňová, Slovník představitelů katolické církevní správy v Čechách 1848-1918, Praha 1995, s. 69.

6 P. Marek, M. Šmíd, Arcibiskup František Kordač. Nástin života a díla apologety, pedagoga a politika, Olomouc 2013, s. 14. 
o wyjątkowo wysokim poziomie, która wzbudzała zainteresowanie i wykraczała poza ówczesną standardową praktykę w tym zakresie, a także twórcza działalność w sferze społecznej i politycznej ${ }^{7}$.

Podczas pierwszej wojny światowej F. Kordač, podobnie jak większość przedstawicieli Kościoła katolickiego, poparł racje monarchii habsburskiej. Ponieważ nie był przychylny żadnej rewolucji ani zmianom w porządku społeczno-politycznym, bronił zasad krajowej legitymizacji politycznej. W tym kontekście utworzenie Czechosłowacji wydawało mu się nie do przyjęcia. Prawie siedemdziesięcioletniemu mężczyźnie było trudno zmienić stabilny wzorzec myślowy, mimo że był on niezgodny z punktem widzenia katolickiej młodzieży akademickiej, a nawet z decyzyjnymi siłami orientacji społeczno-chrześcijańskiej. Ostatecznie jednak podszedł do tego realistycznie i zaakceptował nowy czechosłowacki twór państwowy, który został utworzony w październiku 1918 r. jako jeden z krajów-następców monarchii austro-węgierskiej, o czym świadczy także to, że w tymże roku został członkiem Komitetu Narodowego, a następnie również Rewolucyjnego Zgromadzenia Narodowego, w ramach którego bronił Kościoła katolickiego, katolicyzmu i jego zasad $^{8}$.

Kościół katolicki zdecydowanie nie miał łatwej drogi w Pierwszej Republice Czechosłowackiej. Czesi ulegli sporej radykalizacji za sprawą przerażających doświadczeń pierwszej wojny światowej i jej konsekwencji. Miało to znaczący wpływ na obcesowe, często niesprawiedliwe, a nawet gwałtowne traktowanie Kościoła katolickiego oraz symboli katolicyzmu w Czechach. Liberalna i socjalistyczna część społeczeństwa postrzegały Kościół jako współwinnego kilkusetletniemu austriackiemu ciemiężeniu; organizację Kościoła kojarzono z monarchią habsburską. Początkowy gniew ze strony czeskiego społeczeństwa po ustanowieniu niepodległego państwa w 1918 r. wynikał z pewnych historycznych reminiscencji i konserwatywnej postawy Kościoła katolickiego. Jego ofiarą padło kilka cennych, zabytkowych budowli (np. Kolumna Maryjna na Starym Mieście w Pradze). Z kolei na Słowacji nigdy nie powstał podobny obóz antykatolicki, a przypadki apostazji były nieliczne. Wręcz przeciwnie, tradycyjna religijność Słowaków osłabiła siłę ataków na katolicyzm w Republice.

7 P. Marek, Arcibiskup pražský prof. dr. František Kordač. Nástin života a díla apologety, pedagoga a politika, Olomouc 2005, s. 145-615.

8 A. Neumann, Katolictví a naše národní osvobození, Hradec Králové 1922, s. 64; J. Doležal, Český kněz, Praha 1931, s. 99. 
Mianowanie F. Kordača arcybiskupem praskim 16 IX 1919 r. rozpoczęło być może najważniejszy, ale również ostatni etap życiowej pielgrzymki Kordača - zaczął wówczas 67 rok życia9 ${ }^{9}$ W oczach Stolicy Apostolskiej jawił się jako idealny kandydat ukształtowany przez Rzym, doświadczenie duszpasterskie i środowisko akademickie, który był przedstawiany jako likwidator ruchu reformatorskiego. Stłumił reformacyjny Związek Duchowieństwa Katolickiego (cz. Jednota katolického duchovenstva) i utożsamiał się z oceną kurii dotyczącą wymogów reformacyjnych księży. Jako człowiek ukształtowany przez studia rzymskie ewokujące określone wartości konsekwentnie działał, stosując się do życzeń papieża, gdy próbował realizować idee zasad papieskich w podejściu do spraw kościelnych w Czechosłowacji.

Kręgi polityczne i szersza społeczność katolicka przyjęły mianowanie Kordača w miarę pozytywnie. Przychylnie wyraziło się również duchowieństwo skupione w Czechosłowackiej Partii Ludowej (cz. Československá strana lidová) i wyższe duchowieństwo katolickie, negatywnie natomiast wypowiedzieli się księża reformacyjni reprezentowani przez Związek Duchowieństwa Katolickiego oraz radykalny Klub Księży Reformacyjnych (cz. Klub reformních kněží), którzy byli nieprzyjemnie zaskoczeni wyborem osoby F. Kordača oraz zdumieni sposobem jego wyboru. Związek zorganizował nawet akcję protestacyjną wymierzoną w nowego arcybiskupa i przygotował ankietę rozprowadzoną wśród duchowieństwa, której celem miało być rozpoznanie postaw i która miała stanowić podstawę do wyrażenia niezgody mającej być wyrazem poglądów większej masy ludzi. Akcja się nie powiodła ${ }^{10}$.

W latach dwudziestych F. Kordač przyczynił się w znacznym stopniu do konsolidacji stosunków religijnych w Czechosłowacji, ponieważ w połowie tejże dekady w znaczący sposób włączył się również w czechosłowacko-watykańskie negocjacje $\mathrm{w}$ sprawie modus vivendi. Z drugiej strony nie potrafil zapobiec sekularyzacyjnym trendom i bezwzględnym interwencjom państwa, których celem była eliminacja wpływu Kościoła na szkołę. Nie był również w stanie uniknąć konsekwencji reformy rolnej, w ramach której w latach dwudziestych została odebrana Kościołowi (za kompensacją) część gruntów i lasów ${ }^{11}$. W ramach formacji kapłańskiej odczuwał

9 Čech, 9 I 1927; Národní archiv Praha (dalej NACR), fond Arcibiskupství pražské - ordinariát, inventární číslo 739, karton 176, složka Kordač; Archivio Segreto Vaticano (dalej ASV), fond Archiv apoštolské nunciatury v Československu, busta 10, fascikl 39, ff. 50-55, Micara Gasparrimu 27 X 1919.

10 P. Marek, M. Šmíd, Arcibiskup František Kordač, s. 65; J. Doležal, Český kněz, s. 67.

11 M. Trapl, Církevní pomèry v letech 1848-1938, [w: ] Pražské arcibiskupství 1344-1994. Sborník statí o jeho pưsobení a významu v české zemi, ed. Z. Hledíková a kol., Praha 1994, 
niedobór kapłanów, dlatego kładł nacisk zarówno na stworzenie materialnych warunków, które przyczyniłyby się do zmiany w tym zakresie, jak i na zapewnienie jakości w wychowaniu i kształceniu seminarzystów. Można by się zastanawiać, czy ta tendencja do izolowania młodych chłopców i mężczyzn od zwykłego codziennego życia była najlepszym środkiem mającym na celu ich ochronę przed pokusami i zasadzkami godzącymi w objętą przez nich drogę życiową, ale nie można zaprzeczyć, że podjął on szczery wysiłek, aby wykształcić kapłanów, którzy mieli swym życiem i postępowaniem stanowić wzór dla duchowej wspólnoty i mieli wskazywać właściwą drogę do Boga. Jego rola jako duchowego przywódcy duchowieństwa nie ograniczała się oczywiście tylko do młodej generacji ${ }^{12}$.

Jako arcybiskup położył duży nacisk na regularne odbywanie się konferencji episkopatu, w trakcie których przedkładał biskupom zasadnicze kwestie dotyczące egzystencji Kościoła w państwie. Wynikiem podjętych przez niego działań i narad były liczne wspólne listy pasterskie, które wyrażały palące problemy życia duchowego i kościelnego w państwie. Czuł potrzebę wyrażania siebie nie tylko poprzez okólniki czechosłowackiego episkopatu, ale także za pomocą własnych listów dokumentujących systematyczną refleksję nad różnymi kwestiami, a także poczucie odpowiedzialności, które odczuwał, pełniąc swoją funkcję. Nie trzeba dodawać, że w swojej archidiecezji przeprowadzał regularne wizytacje, których celem było zachęcenie duchownych do działania, ale także kontrola ich posługi duszpasterskiej. Zainteresowanie Kordača sprawami religijnymi w Czechosłowacji z całą pewnością przekraczało granice jego diecezji ${ }^{13}$.

Działalność arcybiskupa w latach dwudziestych odzwierciedlała się (obok zadań reprezentacyjnych) głównie w wysiłkach w dziedzinie prac budowlanych na rzecz szkolenia i kształcenia duchownych (świadczy o tym np. dobudówka gimnazjum arcybiskupiego w Pradze-Břevnovie oraz budowa wydziału teologicznego wraz z seminarium w Pradze-Dejvicach, dotacje finansowe na budowę czeskiego kolegium Nepomucenum w Rzymie (poświęcone w kwietniu 1929 r.), a także zwiększenie liczby budowli sakralnych i budynków administracji kościelnej w miejscach, gdzie było ich zbyt mało. F. Kordač poświęcał się także działalności publicystycznej o cha-

s. 270-271; J. Voženílek, O rozdělení velkostatků k účelu vnitřní kolonizace, Praha 1919, s. 14, 17-19; tenże, Pozemková reforma v Československé republice, Praha 1924, s. 47-48.

12 NACR, fond Arcibiskupství pražské - ordinariát, inventární číslo 860, karton 219.

13 B. Zlámal, Příručka českých církevních dějin. Doba československého katolicismu (1918-1949), VII, Olomouc 2010, s. 88-91; J. Formánek, M. Šmíd, Pastýřské listy 1918-1945, Praha 2017. 
rakterze apologetycznym i parokrotnie swoimi artykułami odnoszącymi się do kwestii społecznych wywołał spore zainteresowanie publiki ${ }^{14}$.

Pod koniec lat dwudziestych prymas Czech miał już za sobą kulminacyjną fazę swojego funkcjonowania jako arcybiskup, a zarazem apogeum swoich ludzkich możliwości. Na wiosnę 1928 r. przeżył atak udaru mózgu, po którym stosunkowo szybko wrócił do swojej pracy. Jednakże od tej pory na jego pracę miały wpływ nie tylko przebyte choroby, ale także sam proces starzenia się. Jeden z ówczesnych obserwatorów mówi o tym, że Kordač coraz bardziej zamykał się w swym świecie filozofa i oddalał od realnego życia. Jego świat został ograniczony tylko do jego własnej osoby, utracił zdolność odpowiedniego reagowania na wyzwania życia codziennego, nie był w stanie wczuć się w sytuację innych osób, w sporach zasłaniał się pełnionym przez siebie urzędem, swoimi uprawnieniami, swoim autorytetem ${ }^{15}$. Prawdopodobnie w tym również należy doszukiwać się źródła jego niemal permanentnych sporów z nuncjuszami apostolskimi w Pradze, który mieszkali i pracowali w pałacu samego arcybiskupa, co sam im zaoferowal, a co z biegiem czasu okazało się niezbyt szczęśliwym rozwiązaniem (od 1929 r. nuncjusze mieszkali już w oddzielnym pałacu w praskim Nowym Mieście). Niebagatelną rolę odegrała także różnica wieku i ogólny styl życia, kiedy to nastąpił konflikt między wyobrażeniami przedstawicieli uniwersalnej władzy papieskiej z życiową skromnością, ascezą i franciszkańskim ubóstwem arcybiskupa Pragi, któremu obce było jakiekolwiek gromadzenie majątku ${ }^{16}$.

Jak już wskazano powyżej, stosunek nuncjuszy apostolskich do osoby arcybiskupa praskiego F. Kordača nie był zbyt przychylny. Krytyka jego osoby i działalności nie była tylko kwestią drugiej połowy lat dwudziestych XX w. - pierwsze oznaki niezadowolenia w związku z jego polityką kościelną pojawiły się już w 1923 r. Pewną rolę odegrał także podeszły wiek Kordača - w 1922 r. skończył siedemdziesiąt lat - a z tym wiązała się częsta zachorowalność, osłabienie sił życiowych i zmniejszenie zaangażowania, podczas gdy w Czechosłowacji lat dwudziestych, będącej pod wpływem silnej fali sekularyzacji i mocnego potencjału elektoratu partii lewicowych, wystąpiła ogromna potrzeba twórczych, pełnych entuzjazmu i niezwykle zaangażowanych osobowości w Kościele, zwłaszcza na najwyższych szczeblach.

\footnotetext{
14 B. Zlámal, Příručka českých církevních dějin, s. 14.

15 J. Doležal, Český kněz, s. 101.

16 NACR, fond Arcibiskupství pražské - ordinariát, inventární číslo 739, karton 176, složka Kordač.
} 
Pierwsze poważne słowa krytyki można znaleźć w podsumowującym raporcie końcowym sporządzonym przez pierwszego nuncjusza apostolskiego w Pradze Clemente Micary. Z jednej strony pochwalił on moralny i duchowny charakter arcybiskupa, rzymskiego ducha, energiczne działania przeciwko schizmatykom - zwłaszcza w styczniu 1921 r., zaraz po ustanowieniu Kościoła czechosłowackiego - i jednoznaczną niezawodność. Natomiast z drugiej strony skrytykowal jego bierność w pracy duszpasterskiej w archidiecezji, brak zainteresowania kontaktem z seminarium i dystans, który trzymał w stosunku do ludzi. W tymże podsumowującym raporcie końcowym C. Micara negatywnie ocenił jego „oschły charakter” oraz praktykę duszpasterską, która nie miała szans na przeniknięcie do serca ludu, ponieważ „brak jej sentymentów i jest nieprzystępna”, co - wg nuncjusza apostolskiego C. Micary - powoduje izolację F. Kordača ${ }^{17}$. Na krytyczne podejście Micary w dużej mierze wpłynęło nieprzyjemne doświadczenie wspólnego mieszkania czy raczej nie zawsze bezkonfliktowe korzystanie ze wspólnych pomieszczeń w latach dwudziestych XX w. - o czym już wspomniano - gdy nuncjatura apostolska mieściła się w budynku Pałacu Arcybiskupiego na placu Hradczańskim w Pradze. Jednak sytuacja ta została uznana za pewne prowizoryczne rozwiązanie tymczasowe, ponieważ nuncjusz apostolski, który z pewnością miał zupełnie inne wyobrażenie o reprezentowaniu Stolicy Apostolskiej, ciężko znosił to, że jest stałym gościem arcybiskupa praskiego F. Kordača i że faktycznie żyje pod jego nieustannym nadzorem ${ }^{18}$.

O ile do połowy lat dwudziestych XX w. ta krytyczna ocena była raczej odosobnionym zjawiskiem, o tyle od lata 1925 r. w pismach do Stolicy Apostolskiej zaczyna pojawiać się już otwarta krytyka arcybiskupa praskiego, którego oskarżano m.in. o brak elastyczności w tworzeniu listu pasterskiego czechosłowackich biskupów ${ }^{19}$, krytykę nuncjatury apostolskiej w Pradze, wyniosłą postawę wobec nuncjusza czy niekorzystną sprzedaż budynku rozległego kolegium jezuickiego - praskiego Klementinum (obecnie Biblioteka Narodowa Republiki Czeskiej, cz. Národní knihovna České republiky) - w centrum Pragi. Antonino Arata był również rozczarowany tym,

17 ASV, fond Archiv apoštolské nunciatury v Československu, busta 5, fascikl 19, f. 83, Micara Gasparrimu, brak datowania.

18 ASV, fond Archiv apoštolské nunciatury v Československu, busta 56, fascikl 501, f. 42, Ciriaci Strimplowi 13 IV 1929.

19 Archivio Storico. Sezione per i rapporti con gli stati (Segreteria di Stato) (dalej ASRS), Cecoslovacchia, IV periodo, fascikl 59, ff. 23-29, Arata Gasparrimu 27 VII 1925. 
że tydzień po niepokojach związanych z uroczystościami ku czci Husa arcybiskup praski wyjechał na wieś i pozostał bierny ${ }^{20}$.

Działania arcybiskupa, jak już wspomniano w poprzednim akapicie, nie uszły krytyce także chargé d’affaires A. Araty, w lecie 1925 r., bezpośrednio po opublikowaniu listu pasterskiego biskupów w związku z uroczystościami ku czci Jana Husa, który jako heretyk został spalony na stosie w 1415 r. za swoją krytykę Kościoła Katolickiego. A. Arata w liście skierowanym do Stolicy Apostolskiej z 6 VIII 1925 r. skarżył się, że

z listu pasterskiego - podobnie jak z osoby F. Kordača - pobrzmiewa doktrynersko-profesorski styl. Wprawdzie F. Kordač przetłumaczył instrukcje i telegram z Watykanu [...], ale nie przyłożył się do tego i nie zrobił tego w ten sposób, by wzniecić uczucia religijne wśród czechosłowackich katolików ${ }^{21}$.

Rozdźwięk między A. Aratą a F. Kordačem pogłębił się także w następnym roku, kiedy to arcybiskup Pragi nie posłuchał nakazu A. Araty, żeby poszczególne kwestie sporne w stosunkach czechosłowacko-watykańskich nie były ujawniane w prasie, i uczynił to na łamach gazety „Prager Presse”22.

Punkt widzenia nuncjusza apostolskiego P. Ciriaciego na temat zagadnień religijnych był w wielu aspektach odmienny od punktu widzenia krajowego duchowieństwa, zwłaszcza arcybiskupa praskiego, F. Kordača. Prawdą jest, że osobiste nieporozumienia między nimi - postaciami tak różnymi pod względem charakteru, wieku i stylu życia - zaznaczyły się już po przybyciu Ciriaciego do nuncjatury apostolskiej na początku 1928 r. Kiedy w trakcie jednego ze swoich licznych pobytów w Rzymie ambasador Czechosłowacji przy Stolicy Apostolskiej Vladimír Radimský rozmawiał z P. Ciriacim 19 X 1928 r., nuncjusz apostolski nie krył swojego krytycyzmu wobec arcybiskupa, o czym informował Pragę:

Nuncjusz skarżył się, że arcybiskup stwarza mu trudności przez swój upór, czyli brak zrozumienia dla dyplomatycznej misji nuncjusza (Mons. Ciriaco nie podał bliższych szczegółów) - podobno nie spodziewał się tego po tym, co dla niego zrobił do tej pory. Arcybiskup podobno był doktrynerem, który często sprawia wrażenie, jakby przytakiwał, ale potem i tak robi swoje, a przy tym często postępuje w sposób wyraźnie niedyplomatyczny, co osłabia pozycję mons. Ciriaciego (krytykuje arcybiskupa, mówił Mons. Ciriaci, a w jego głosie pobrzmiewała nuta

\footnotetext{
20 Tamże, f. 28, Arata Gasparrimu 27 VII 1925.

21 Tamże, f. 50, Arata Gasparrimu 6 VIII 1925.

22 Tamże, fascikl 70, f. 51, Arata Gasparrimu 8 I 1926.
} 
zdenerwowania). Jeśli arcybiskup będzie trwał w swoim uporze, nuncjusz obawia się, że może mu to znacznie skomplikować misję dyplomatyczną... ${ }^{23}$

Z drugiej strony, także wielu przedstawicieli Kościoła, którzy mieli kontakt z nuncjuszem apostolskim P. Ciriacim, zdawało sobie sprawę ze złożoności i problematyczności jego pozycji w Czechosłowacji. Jak wspominał później Leopold Škarek (w okresie misji dyplomatycznej Ciriaciego w Czechosłowacji był prowincjałem jezuitów), który podjął próbę naszkicowania medalionu nuncjusza apostolskiego:

Był temperamentnym Włochem, pewnym siebie, władczym prałatem (autokratą), był intelektualistą i wielkim dyplomatą, jednakże postępował mało psychologicznie, zamiast stopniowo i systematycznie rozpracowywać problem, chciał załatwić wszystko gwałtownie; nie znał czeskiego, jednak ulegał wpływom różnych partyjnych mądrali; był doskonałym znawcą stosunków i kwestii religijno-politycznych w Czechosłowacji, był prawdziwym przyjacielem Towarzystwa Jezusowego, czego nie kry124.

Współczesny historyk Kościoła Miloš Trapl określił P. Ciriaciego przymiotnikiem „porywczy”25.

W szczegółowym raporcie wysłanym do Watykanu, datowanym na październik 1928 r., P. Ciriaci określił praskiego biskupa F. Kordača jako chorego i starego człowieka, który przestał sobie radzić z przydzielonymi zadaniami, bowiem są one już ponad jego sily:

Kordač ma dwie-trzy wady, na które cierpi cały ten naród. W pierwszym rzędzie brakuje mu serdeczności, czy raczej należałoby powiedzieć: cierpi na brak poczucia prawdy, tzn. zgodę lub niezgodę wyraża z obojętnością, a dzień później z łatwością powie coś zupełnie przeciwstawnego. W drugim rzędzie ma immanentnego ducha opozycji do władz, zwłaszcza do Stolicy Apostolskiej. Jego podziw dla Stolicy Apostolskiej może być szczery, ale to jest raczej tylko odbicie niż szczere uczucie ${ }^{26}$.

$\mathrm{W}$ innym raporcie, który prawdopodobnie powstał w tym okresie, nuncjusz apostolski P. Ciriaci wyraził zaniepokojenie z powodu niezadowalającego zarządza-

23 Archiv Masarykova ústavu a archivu AV ČR, fond Edvard Beneš - oddělení I., karton 64, sign. R194 (Církve 1926-1929), Radimský 22 X 1928.

24 B. Pitrun, Jadrné memento. Životopisný nástin českého provinciála jezuitů Leopolda Škarka SJ (1874-1968), Velehrad-Roma 2008, s. 163.

25 M. Trapl, Krize českého politického katolicismu v první polovinè třicátých let 20. století, Acta Universitatis Palackianae Olomucensis. Facultas Philosophica 21 (1981), s. 67.

26 ASRS, Cecoslovacchia, IV periodo, fascikl 139, ff. 52-53, resp. fascikl 143, f. 5. 
nia archidiecezją w Pradze, którą określił jako najgorzej zarządzaną część państwa czechosłowackiego, gdzie wyraźnie zmniejsza się liczba wierzących (!). Wyraził również swoje obawy w związku z dalszym pełnieniem przez arcybiskupa urzędu najwyższego czeskiego pasterza ze względu na jego zaawansowany wiek - Kordač był prawie dwukrotnie starszy od Ciriaciego - oraz zły stan zdrowia, i zasugerował Watykanowi, że już teraz trzeba myśleć o jego następcy. Według P. Ciriaciego jego następcą powinien zostać młody i zdecydowany dostojnik, który zająłby się rozwiązaniem tych pilnych zadań, które zostały zaniedbane przez F. Kordača - czyli konsolidacją i skutecznym funkcjonowaniem wszystkich seminariów diecezjalnych, jak również ustanowieniem mniejszych seminariów we wszystkich diecezjach, zagrzewaniem duchowieństwa do prowadzenia prawdziwego życia duszpasterskiego, a także terytorialnym uporządkowaniem diecezji oraz tworzeniem nowych parafii, wytrwałą opieką w propagowaniu katolickich działań, aktywniejszym wsparciem dla wszystkich zakonów i instytucji religijnych w działalności duszpasterskiej (zwłaszcza w działalności misyjnej wśród ludzi, powołań duchownych oraz szkolenia nauczycieli), a wreszcie rozwiązywaniem złożonych problemów edukacyjnych ${ }^{27}$. Jak sygnalizował L. Škarek, pozostaje kwestią otwartą, czy P. Ciriaci, interweniując w sprawie zarządzania archidiecezją w Pradze przez F. Kordača, nie przekroczył swoich uprawnień ${ }^{28}$.

Po serii rokowań z sekretarzem stanu P. Gasparrim i niektórymi kongregacjami Stolicy Apostolskiej, nuncjusz apostolski P. Ciriaci 3 VII 1931 r. nakłonił wyczerpanego F. Kordača po ponad dwunastu latach czynnej służby apostolskiej do dymisji, która została przedstawiona społeczeństwu czechosłowackiemu jako rezygnacja samego Kordača ze względu na podeszły wiek.

Papież Pius XI przyjął jego rezygnację i mianował go arcybiskupem tytularnym Amazji i asystentem papieskiego tronu. Raport praskiej kapituly metropolitalnej, opublikowany w prasie 14 VII 1931 r. o jego rezygnacji z urzędu arcybiskupa „ze względu na bardzo podeszły wiek i długotrwałą chorobę"29 był dla społeczeństwa dość zaskakujący; wysocy dostojnicy kościelni zwykle kończyli swoje urzędowanie śmiercią. Ze źródeł w watykańskich archiwach jasno wynika, że abdykacja Kordača nie była impro-

27 Tamże, fascikl 132, ff. 9-11, Gasparri Ciriacimu 22 II 1929; M. Šmíd, Pietro Ciriaci neúspěch v Československu klíčem k jeho dalšímu vzestupu?, Historica Olomucensia. Sborník prací historických 44 (2013), nr 32, s. 64.

28 B. Pitrun, Jadrné memento, s. 163.

29 Československá republika, 14 VII 1931; Lidové listy, 14 VII 1931; Národní listy, 14 VII 1931; Pražský večerník, 14 VII 1931; Právo lidu, 14 VII 1931 itd. 
wizowaną decyzją, ale raczej wynikiem wieloletniego niezadowolenia P. Ciriaciego z zarządzania diecezją praską oraz z kierowania Kościołem katolickim w Czechosłowa$\mathrm{cji}^{30}$. Była przygotowywana przez dłuższy czas i najprawdopodobniej została sfinalizowana podczas pobytu Ciriaciego w Rzymie wiosną 1931 r. Skargi Ciriaciego na arcybiskupa Pragi zostały zbadane przez Kongregację Nadzwyczajnych Spraw Kościelnych, która w czerwcu 1931 r. potwierdziła zasadność zarzutów nuncjusza i przychyliła się do dymisji Kordača oraz przyzwoliła na jego przejście na emeryturę ${ }^{31}$.

Z archiwów watykańskich i nowo wydanych pamiętników L. Škarka wiemy już teraz, że tym, który 2 lipca wezwał do nuncjatury prowincjała zakonu jezuitów L. Škarka i bez podania przyczyn namawiał go, aby w swoim imieniu wezwał arcybiskupa praskiego F. Kordača do dymisji, był właśnie nuncjusz apostolski P. Ciriaci. L. Škarek prosił nuncjusza, aby zwolnił go z tego przykrego obowiązku, ale P. Ciriaci podjął już decyzję̧ ${ }^{32}$. Dlatego 3 VII 1931 r., dzień po powrocie arcybiskupa z bierzmowania i wizytacji w regionie Českiego Brodu, prowincjał jezuitów stawił się przed F. Kordačem na zamku w Břežanach niedaleko Pragi i przedstawił mu dwa pisma: pierwsze było aktem abdykacji, drugie natomiast przynosiło alternatywę w postaci akceptacji koadiutora, który przejąłby wszystkie prawa arcybiskupa, a F. Kordač przyjąłby rolę obserwatora wydarzeń. Dokumenty zawierały pogróżkę, że jeśli arcybiskup nie podpisze któregoś z nich, wówczas zostanie przeciwko niemu wszczęte postępowanie według prawa kanonicznego.

Watykański dyplomata P. Ciriaci uważał, że na miejsce Kordača niezwłocznie powinien być wyznaczony zdolny dostojnik, który rozwiązałby wszystkie pilne zadania, które były przez F. Kordača długo zaniedbywane, szczególnie te związane z konsolidacją i skutecznym funkcjonowaniem wszystkich seminariów diecezjalnych, jak i z ustanowieniem mniejszych seminariów we wszystkich diecezjach, z zachęcaniem duchownych do prawdziwego życia duszpasterskiego, z terytorialną organizacją diecezji i tworzeniem nowych parafii, a także z nieustanną pieczą w promowaniu działalności katolickiej, aktywniejszym wsparciem dla wszystkich zakonów i instytucji religijnych czynnych w działalności duszpasterskiej, zwłaszcza w działalności misyjnej wśród ludu, z powołaniami do stanu duchownego i ze szkoleniem nauczycieli, a także z rozwiązaniem złożonych problemów edukacyjnych. Wkrótce następcą Kordača został dawny biskup Hradca Králové o rzymskiej formacji i z doskonałymi

\footnotetext{
30 ASRS, Cecoslovacchia, IV periodo, fascikl 143, f. 5, Ciriaci Gasparrimu 21 XI 1928.

31 Tamże, fascikl 144, ff. 17-19, Pacelli Ciriacimu 11 VI 1931.

32 B. Pitrun, Jadrné memento, s. 165-166.
} 
kontaktami w środowisku watykańskim, Karel Kašpar, który później stał się pierwszym czechosłowackim kardynałem po roku 1918.

Kilka dni po swojej rezygnacji F. Kordač udzielił wywiadu redaktorowi czasopisma „Národní polityka”, Janowi Hejretowi, w którym opowiedział o okolicznościach swojej rezygnacji i oświadczyl, że nie była ona spowodowana jego problemami zdrowotnymi ani utratą woli służenia Kościołowi i ludowi katolickiemu w związku z podeszłym wiekiem. Oświadczył także, że z zajmowanego stanowiska nie odszedł $\mathrm{z}$ własnej woli oraz że do podpisania aktu abdykacji został przez kręgi kościelne de facto zmuszony, a za jego rezygnacją stoi nuncjusz apostolski Pietro Ciriaci, z którym miał i wciąż ma wiele nierozwiązanych sporów ${ }^{33}$. Wywiad Hejreta stał się bodźcem do wywołania afery, która była szeroko dyskutowana aż do jesieni 1931 r. w prasie czechosłowackiej i komentowana także w prasie zagranicznej oraz przez ambasadorów ${ }^{34}$.

Krajowa kampania prasowa wzniecona wokół rezygnacji Kordača w sposób jednoznaczny została zwrócona przeciwko Kościołowi katolickiemu, a zwłaszcza przeciwko nuncjuszowi apostolskiemu jako przedstawicielowi Stolicy Apostolskiej. 30 VII 1931 r. doszło wieczorem przed nuncjaturą apostolską znajdującą się przy ulicy Voršilskiej w centrum Pragi do demonstracji około 150 przeważnie młodych ludzi, którzy krzyczeli „hańba!” i wychwalali arcybiskupa F. Kordača ${ }^{35} .9$ sierpnia udała się do F. Kordača do Břežan grupa wierzących, aby wyrazić mu swoją solidarność i wsparcie oraz współczucie dla jego losu; autorzy reportaży podkreślali, że F. Kordač przemówił do ludzi przed budowlą zamkową „jasnym, mocnym głosem i z niezwykłym temperamentem", co miało stanowić dowód na to, iż uzasadnianie rezygnacji chorobą i podeszłym wiekiem nie jest oparte na prawdzie ${ }^{36}$. W lecie jednakże F. Kordač oświadczył, że nie będzie już podawać do prasy żadnych dalszych wypowiedzi ani udzielać wywiadów i potwierdzil, że jego rezygnacja jest ostateczna.

Niektóre niemieckie stowarzyszenia kapłanów oraz gazety, np. „Deutsche Presse” czy „Egerland”, odrzucały jednakże oficjalną interpretację rezygnacji Kordača. Uważały ją za wymuszoną i kierowały ostry atak w nuncjusza P. Ciriaciego, krytykując jego podejście i zachowanie wobec F. Kordača; nuncjusz apostolski postanowił wobec tego

33 Národní politika, 17 VII 1931; Večerník Práva lidu, 17 VII 1931; Lidové noviny, 18 VII 1931; ASRS, Cecoslovacchia, IV periodo, fascikl 144, f. 29, Ciriaci Pacellimu 22 VII 1931.

34 P. Marek, M. Šmíd, Arcibiskup František Kordač, s. 106.

35 Večerník Práva lidu, 31 VII 1931; Pražský večerník, 31 VII 1931; Národní osvobození, 1 VIII 1931.

36 Polední list, 10 VIII 1931. 
wycofać swoją kościelną dla nich aprobatę ${ }^{37}$. Przez swoje publiczne wypowiedzi pod adresem P. Ciriaciego w czasopiśmie „Národní polityka” pod pseudonimem Hroznata został zawieszony i zmuszony udać się na długotrwały urlop profesor Wydziału Teologicznego w Pradze, Vojtěch Šanda. Jesienią 1931 r. - po odbyciu się konferencji episkopatu czechosłowackiego w Ołomuńcu - afera wokół osoby Kordača ucichła ${ }^{38}$.

Misja Ciriaciego w Czechosłowacji zakończyła się dwa lata później, gdy na zachodzie Słowacji, w Nitrze, od 13 do 15 VIII 1933 r. odbywały się uroczystości w 1100. rocznicę założenia pierwszego chrześcijańskiego kościoła przez księcia Pribina. Obchody na krótko przed rozpoczęciem zostały objęte patronatem przez rząd czechosłowacki, który zmienił skład członków komitetu przygotowawczego i wysłał na uroczystości dużą delegację rządową na czele z premierem rządu Janem Malypetrem. Znaleźli się w niej także Milan Hodža, Ivan Dérer, Jan Šrámek i inni ministrowie oraz przedstawiciele wyższej hierarchii kościelnej, co oczywiście rozdrażniło reprezentantów słowackich, tym bardziej że do udziału w uroczystości nie zostały zaproszone ważne osobistości słowackiej myśli autonomistycznej ${ }^{39}$.

Uroczystości w Nitrze odbiły się silnym echem zarówno w parlamencie, jak i na posiedzeniu rządu jesienią 1933 r. Minister Edvard Beneš próbował wprawdzie uspokoić napiętą sytuację, zwłaszcza ze względu na zainteresowanie zagranicy, i publicznie dystansował się od ataków pisma „Venkov”, centralnej trybuny partii agrarnej, jednakże krytyczne artykuły ukazywały się nadal ${ }^{40}$. W obronie nuncjusza apostolskiego stanął wówczas tylko słowacki ksiądz, polityk i prezes Słowackiej Partii Ludowej (słow. Slovenská ludová strana) Andrej Hlinka, który 11 IX 1933 r. wysłał mu list. Obdarzony wspomnianym temperamentem P. Ciriaci w przypływie goryczy odpowiedzial, ostro uderzając w praski rząd:

Podczas gdy w Pradze Ojciec Święty jest bezpośrednio lub w osobie swego przedstawiciela obrażany w sposób, który ignoruje wszystkie reguły między-

37 J. Šebek, Mezi křižem a národem. Politické prostředí sudetonèmeckého katolicismu v meziválečném Československu, Brno 2006, s. 181-183.

38 Österreichisches Staatsarchiv in Wien, Archiv der Republik, Bundeskanzleramt/ Auswärtige Angelegenheiten, Neues Politisches Archiv, Liasse Tschechoslowakei, Karton 691, Marek 8 X 1931; P. Marek, M. Šmíd, Arcibiskup František Kordač, s. 140-142.

39 A. Magdolenová, Pribinove slávnosti v Nitre roku 1933, [w:] Slovensko sa rodilo v Nitre. K 60. výročiu Pribinových slávností v Nitre roku 1933 a prvému výročiu prijatia Ústavy SR, ed. S. Bajaník, Martin 1993, s. 359.

40 E. Hrabovec, Pribinove slávnosti v Nitre a vypovedanie nuncia Ciriaciho z Česko-Slovenska 1933, [w: ] Studia Historica Tyrnaviensia V, ed. Jozef Šimončič, Trnava 2004, s. 79. 
narodowego protokołu dyplomatycznego, wy, Słowacy, okazaliście wielkiemu autorytetowi Ojca Świętego należyty szacunek.... ${ }^{41}$

Prawdziwym problemem jednak nie było poparcie dla słowackiego obozu katolickiego przez przedstawiciela Stolicy Apostolskiej, ale wyrażenie sympatii przez nuncjusza dla narodu słowackiego, który był przez stronę czeską uważany za część składową narodu czechosłowackiego, natomiast wypowiedzi nuncjusza w tym dość niefortunnym czasie były wsparciem dla wzbierających tendencji słowackiego autonomizmu i stanowily obrazę rządu ${ }^{42}$.

Afera Ciriaciego spotkała się ze sporym zainteresowaniem zarówno za granicą, jak i wśród dyplomatów akredytowanych przez rząd czechosłowacki. 21 VIII 1933 r. ambasador niemiecki w Pradze Walter Koch poinformował Berlin o wydarzeniach w Czechosłowacji, czym zwrócił uwagę na żywą kampanię prasową w kraju, wznieconą przez ataki na Stolicę Apostolską i osobę nuncjusza apostolskiego w Pradze czasopismo agrarnego „Venkov”. Miesiąc później W. Koch poinformował o trwającej aferze w szczegółowym dziesięciostronicowym raporcie, przy czym nie zapomniał opisać P. Ciriaciego jako „przebiegłego i bezwzględnego, ale w swym zamknięciu skądinąd sympatycznego człowieka renesansu, który już od dawna nie mówił dobrze o rządzie czechosłowackim" ${ }^{3}$.

Następnie czechosłowacki rząd potępił pismo nuncjusza, które uznał za ingerencję w wewnętrzne sprawy kraju, atak na Pragę i wsparcie dla słowackiej autonomii. Zwrócił się z prośbą do Stolicy Apostolskiej o wezwanie P. Ciriaciego do Rzymu ad verbum audiendum, co faktycznie oznaczało jego koniec, a także zakończenie jego czechosłowackiej misji w październiku 1933 r. „Urlop zdrowotny” Ciriaciego, jak to oficjalnie określała strona watykańska, który był pierwotnie zaplanowany do 31 XII 1933 r., został rozciągnięty na zawsze i nuncjusz apostolski nie powrócił już do Pragi ${ }^{44}$. Gdy afera związana z Ciriacim ucichła całkowicie, były praski nuncjusz

${ }^{41}$ J. Kovtun, Republika v nebezpečném světè. Éra prezidenta Masaryka 1918-1935, Praha 2005, s. 737.

42 E. Hrabovec, Pribinove slávnosti, s. 81.

43 Deutsche Gesandtschaftsberichte aus Prag. Innenpolitik und Minderheitenprobleme in der Ersten Tschechoslowakischen Republik, IV (1933-1935), ed. H. Dolezel, S. Dolezel, München 1991, s. 61-63.

44 Archiv Ministerstvo zahraničních věcí ČR v Praze, Politické zprávy - Vatikán, 1934, Radimský 2 I 1934; tamże, Zastupitelský úřad - Vatikán, 1920-1939, karton 2, Radimský 31 X 1933; Z. Kárník, České země vére První republiky (1918-1938), II, Praha 2002, s. 179. 
apostolski znajdował się już gdzieś w Portugalii, gdzie spędził kolejne dwadzieścia lat. Katolicka Portugalia, do której szczerze przylgnął, stała się jego drugim domem.

Były arcybiskup F. Kordač spędził resztę swojego życia na zamku w Břežanach niedaleko Pragi, w samotności, oddzielony od innych kapłanów, chory, ale z pokorą i cierpliwością znoszący swój los. Zmarł 26 IV 1934 r. w Pradze, w nowym szpitalu Braci Miłosierdzia, gdzie został przeniesiony na własną prośbę po urazie nogi. Pogrzeb odbył się w poniedziałek 30 kwietnia w katedrze św. Wita, Wacława i Wojciecha na Zamku Praskim, gdzie pożegnali go oficjalni przedstawiciele Kościoła, przedstawiciele życia publicznego i państwa czechosłowackiego na czele z przewodniczącym Zgromadzenia Narodowego Františkiem Staňkiem ${ }^{45}$.

Jak wykazano powyżej, szeroko zakrojona merytoryczna krytyka arcybiskupa praskiego i prymasa Czech F. Kordača, która wyszła spod pióra nuncjusza apostolskiego P. Ciriaciego w drugiej połowie lat dwudziestych nie była motywowana względami emocjonalnymi i osobistymi, jak dotychczas myślano, ale była najzupełniej racjonalna. Dobrze przemyślana, odpowiednio dozowana i tendencyjnie napisana przekonywała stopniowo Watykan, że przyszłość wraz z rozległymi, wszechobecnymi i niezbędnymi zmianami zarówno w archidiecezji praskiej, jak i we wszystkich diecezjach w kraju nie powinna być łączona z osobą F. Kordača. Krytyczne nastawienie przedstawiciela Stolicy Apostolskiej i jego raporty do Watykanu z przełomu lat dwudziestych i trzydziestych XX w. były najbardziej prawdopodobnym powodem tego, że Stolica Apostolska w 1928 r., z okazji dziesiątej rocznicy powstania państwa, nie spełniła żądania czechosłowackiego Kościoła i kręgów politycznych na czele z ministrem spraw zagranicznych E. Benešem, późniejszym prezydentem Czechosłowacji, i nie mianowała F. Kordača kardynałem ${ }^{46}$.

Jak już wspomniano, pierwszym czechosłowackim kardynałem został mianowany następca Kordača na stanowisko arcybiskupa praskiego K. Kašpar, który został „wyróżniony” w ten sposób za pomyślny przebieg kongresu eucharystycznego w Pradze w lecie 1935 r. oraz za pomyślne wdrażanie modus vivendi. Stało się to 16 grudnia. Powołanie osoby K. Kašpara było także w dużej mierze wynikiem jego poufnych kontaktów z watykańskimi dygnitarzami kościelnymi po 1918 r., dobrych osobistych relacji z nuncjuszami apostolskimi w Pradze, głębokiej wiedzy teologicznej, a także - co równie istotne - rzymskiego uformowania, które nabył pod koniec XIX w. Tym sposobem był to pierwszy czeski dostojnik kościelny po powstaniu

45 P. Marek, M. Šmíd, Arcibiskup František Kordač, s. 28.

46 ASRS, Cecoslovacchia, IV periodo, fascikl 132, f. 17, Ritter a Gaspari 13 I 1928. 
Czechosłowacji w 1918 r., który otrzymał to wyróżnienie, pozostali kardynałowie z szeregów czeskich księży byli powoływani dopiero po 1945 r. To jednak już inna historia.

\section{Summary}

The study entitled František Kordač, Archbishop of Prague and Primate of the Czech Republic in 1919-1931. A high dignitary of the Church who did not become a cardinal revolves around František Kordač, a Church dignitary and university professor who became the Archbishop of Prague and the Czech Primate in 1919. Although until 1918, he belonged to conservative Catholics, he quickly became familiar with the new republic. With his Roman formation, intellectual outlook and an understanding of the national affairs, he became an ideal candidate for the Prague archbishopric. In the 1920s, he made a significant contribution to the Church history in the republic and contributed to the establishment of Catholicism in Czechoslovakia. However, despite his high priestly, personal and human qualities, he never became a cardinal. The aim of this study is to provide an answer why this never happened.

Nadesłany 3 IV 2019

Nadesłany po poprawkach recenzyjnych 26 I 2021

Zaakceptowany 29 I 2021

Doc. PhDr. Marek Šmíd, Ph.D.

Katedra církevních dějin a literární historie

Katolická teologická fakulta

Univerzity Karlovy

Thákurova 3

16000 Praha 6

email:smidma@seznam.cz 